\title{
Development Finance Strategies, Agricultural Growth and Poverty Reduction in Emerging Economies: Evidence from Nigeria
}

\author{
Edward Ogbonnia Eleje ${ }^{1}$, Eze Okechukwu Agha ${ }^{2}$, Abel Haruna Habila ${ }^{1}$ \\ ${ }^{1}$ Department of Banking and Finance, Federal University, Wukari, Nigeria \\ ${ }^{2}$ Liquidity Management Unit, Treasury Department Keystone Bank Limited, Lagos, Nigeria
}

Email address:

eddieelyg@yahoo.com (E. O. Eleje)

\section{To cite this article:}

Edward Ogbonnia Eleje, Eze Okechukwu Agha, Abel Haruna Habila. Development Finance Strategies, Agricultural Growth and Poverty Reduction in Emerging Economies: Evidence from Nigeria. International Journal of Accounting, Finance and Risk Management.

Vol. 6, No. 3, 2021, pp. 85-93. doi: 10.11648/j.ijafrm.20210603.13

Received: December 1, 2020; Accepted: July 27, 2021; Published: August 6, 2021

\begin{abstract}
Development finance issues have appeared very topical in extant literatures and notable political cum socioeconomic discussions in recent time due basically to its desideratum and criticality to aggregate development of emerging economies. This article investigated development finance strategies and their effects on agriculture and poverty reduction in Nigeria. Specifically, the study examined the impact of agro-financing on agricultural development, and; the impact of industrial financing on poverty eradication in Nigeria. A computer based regression and correlation analysis aided by the IBM SPSS software version 23 was employed to test two formulated hypotheses of the study. Based on the findings from the empirical evaluation, the researcher made two major conclusions that; agro-finance does not have significant positive effect on agricultural development in Nigeria. Secondly, industrial finance does not have significant positive effect on poverty eradication in Nigeria. In line with these conclusions, the study recommends that government should place higher priority on directed credit control scheme such as ACGSF to enable such schemes yield the desired result of improving the agricultural sector and poverty reduction. Secondly, directed credit programmes to SMEs like small and medium enterprise equity investment scheme (SMEEIS) should be supervised adequately and made to work effectively. Lastly, proactive surveillance should be activated by government to checkmate unhealthy practices by lending institutions which could impinge lending integrity and dampen the trust of investors.
\end{abstract}

Keywords: Development Finance, Agricultural Growth, Poverty Reduction

\section{Introduction}

Agriculture has maintained a leading role in the economic development of emerging economies. Undoubtedly, it has remained a very significant catalyst of growth, wealth creation, employment generation and poverty amelioration in the sub-Saharan Africa. Even in the entire African continent, agriculture is also the ultimate economic mover and contributes 20 to 30 per cent of Africa's gross domestic product $[51,13]$. In Nigeria precisely, from the immediate post-independence until today, agriculture has sustained its leading role as the greatest employer of labor. Presently in Nigeria, agriculture still employs over 60 per cent of the nation's active labor force, generates food and income for the growing population and provides essential raw materials for industrialization $[39,6]$. The post-independent Nigeria of the 60 s profoundly relied on agro-commodity exports for her foreign exchange earnings. Within this era, share of agriculture to total export surged to approximately $90 \%$.

However, while agriculture remains the backbone of the economy of most developing countries, the sector unfortunately has drastically lost its place of pride to the mineral sector in Nigeria and precisely oil sector in the last four decades. The country's annual contribution of agriculture to total exports has plummeted to about 5 per cent in recent time $[35,13]$. Agricultural output has also 
progressively straggled behind the demand for local consumption while agro-raw material requirements have dawdled significantly thus affecting industrial productivity. Painfully, the country has reversed from net earner to net importer of most of her traditional exports such as palm oil, rubber, groundnut, raw cotton and even toothpick. Research findings have revealed some factors responsible for this prevailing miserable performance of the sector prominent among these is inadequate agricultural development finance strategies $[37,15,13]$.

Moreover, government annual expenditure appropriation to agriculture which hitherto served as financing bedrock for the sector has drastically dropped far below continental and global average. This is because, the expenditure budget to agriculture failed to achieve the set goals of food self-sufficiency, self-reliance, poverty reduction and rural development hence the government option of alternative development financing strategies via directed credit as part of her monetary policy objective. The government's rationale for directed credit policy is to institute a workable agricultural development financing strategies as well as programs and institutions that could provide direct micro and macro credit facilities to small, medium and large-scale agricultural producers, processors and marketers. It is argued $[28,16,13]$ that this strategy can trigger massive agricultural development and reposition Nigeria better to actualizing the primary goals of food self-sufficiency, self-reliance, poverty reduction and rural development. But this argument has not received adequate empirical evaluation and existing studies are more so inconclusive. This study is therefore a further contribution to filling the foregoing research gap. Specifically, the study examined the impact of agro and industrial development financing on agricultural development and poverty eradication in Nigeria. The study is envisaged to benefit banks and other financial intermediaries, small and large-scale farmers, agro allied firms, economic watchers, commodity market regulators, government, policy analysts and the general public.

\section{Conceptual Clarifications}

\subsection{Development Finance}

The concept 'development finance' defies a clear-cut conceptualization despite the surfeit of literature that has emerged in that direction. The definition is both relative and dynamic varying from country to country and even overtime. It depends to a greater extent on the country's level of development. Research evidence [14] identified notable criteria often used on an arbitrary mix in definition to include relative size of available fund; financial strength of existing funding firms; and, the level of development of the economy. However, one discernible conclusion from available literature is that the term is always used in reference to financial resources made available for development. This implies that such resources could be macro or micro in nature so long as it is devoted solely to activities capable of enhancing development in a nation [12].

Development finance in this study will be based on the micro economic perspective since Nigeria's policy agenda on industrialization is presently focusing on small and medium sized enterprise development. It is therefore conceptually preferable to adopt the micro finance approach in defining the term. Consequently, development finance shall for this purpose refers to the procurement of financial support and ancillary financial services to erect infrastructure which will stimulate the productive and enterprising activities of micro and medium sized businesses. It will also include the delivery of small credit facility to the poor who are traditionally not served by the conventional financial system [3] to enable them engage in productive business activities capable of stimulating growth in the economy. One obvious fact however arises from these definitions. The emphasis of development finance is not necessarily on the credit recipient but on the purpose of the fund. The position taken in [14] is significant. The study argues that development finance objectives require that fund allocation should result in positive increase in the nations GDP. Their argument is hinged on their perception of the concept. They define development finance as that finance and other forms of credits facilities required in an economy for correcting societal economic imbalances; such that hampers growth, lowers per capita income, increases poverty level, worsens unemployment and stalemates the wellbeing of the citizenry.

\subsection{Agricultural Finance}

Agricultural finance or credit defines the loan advanced to farmers of all categories including ranch operators to support their farming activities of planting, weeding, chemical application, crop harvesting as well as livestock feeding and care for the purpose of human satisfaction and food security [9]. Going by size categorization or timing of farm projects, agricultural credit can be overdraft, short tenured, medium tenured, or long tenured. Loans advanced to farmers for farm inputs are often paid directly to the suppliers who in turn is obligated to furnish the bank with evidence of delivery. The essence is to avert diversion of fund by dubious farmers, a feat very common among Nigerian farmers [34].

Agricultural credit is a desideratum to the agricultural sector. This is because, it reactivates and modernizes all forms of agricultural enterprises considered economically feasible, viable and desirable to the achievement of the nation's economic goals of self-sufficiency in agricultural production and food security [32]. Above all, agricultural credits cushion farmers" financial burden and instead, provide significant incentive opportunities for them to adopt new technologies which would have been impossible or very difficult. Hence, credit provision empowers farmers to switch quickly to modern technologies which in turn enhance their growth, productivity and contribution to the Nation's gross domestic product (GDP). 


\subsection{Agro-Credit Finance Strategies in Nigeria}

\subsubsection{Agricultural Credit Guarantee Scheme Fund (ACGSF)}

Formed by decree No. 20, 1977 and commenced operation by 1978 , the scheme basically was to induce the then commercial banks now deposit money banks (DMBs) to provide adequate financial succor to the agricultural sector. Specifically, the scheme anchored by the Central Bank of Nigeria $(\mathrm{CBN})$ provides $75 \%$ guarantee against default to bank loans to farmers. However, in recent time, DMBs patronages to this scheme have significantly eroded with reasons that loan commitments take time to recover. Secondly, banks confidence on the CBN guarantee has grown weak due partly to frequent loan default by loan clients and huge backlogs of long overdue (spanning over twenty years) unsettled claims by the guarantor, the CBN. The highlighted unattractiveness has indeed diminished the trust and confidence of DMBs in not only the ACGSF but also in other related government financing schemes.

\subsubsection{Bank of Agriculture (BOA)}

BOA was formally and recently known as Nigeria Agricultural Cooperative \& Rural Development Bank (NACRDB). The bank was formed in the late 2000 from the amalgamation of Nigeria Agricultural Cooperative Bank (NACB), Peoples Bank of Nigeria (PBN) and Family Economic Advancement Programme (FEAP) respectively. The BOA is jointly owned by the government and the Central Bank of Nigeria. The bank's role is basically to provide rural finance in the rural landscape to boost agricultural productivity. The bank however could extend its line of deposit mobilization and credit allocation to urban clients. By law, the bank is required to lend $70 \%$ of its loan portfolio at single digit interest rates through loans of $\mathrm{N} 250,000$ $(\$ 1,666)$ or less [9]. Meanwhile, the bank`s viability has seriously been affected by poor repayment rates and interest rate cap limiting its ability to satisfying the numerous loan demands of its target clientele.

\subsubsection{Agriculture Credit Cooperative Scheme}

This scheme used to be rare in Nigeria due to traditional views on sharing personal wealth information. Today, it is fast growing and predominant in northern Nigeria precisely in Adamawa, Gombe and Bauchi state respectively where experience has been positive. The scheme involves association of farmers from the same line of activity who work for the common good of members. The group influences credit accessibility from government and banks and at the same time, ensures proper pricing and sales of their agricultural products. Examples include cassava growers' association, rice growers' association, cocoa farmers' association etc. Small-scale cooperatives are becoming common across the country since most formal financial providers will only lend to farmers through this vehicle. These cooperatives are usually stand-alone entities and are not federated under an apex body. Cooperatives provide the required guarantees which the individual farmer cannot provide. Currently, there is a Directorate of Cooperatives in the Federal Ministry of Agriculture with more than 30,000 registered cooperatives spread across the country.

\subsubsection{National Poverty Eradication Programme (NAPEP)}

This is a programme initiated by the Nigerian government in 2001 to replace the earlier Poverty Alleviation Programme. Working in collaboration with the National Poverty Eradication Committee (NAPEC) to coordinate and monitor all poverty eradication activities, NAPEP aims at developing plans and guidelines towards reduction of absolute poverty mostly in the rural areas of Nigeria [29]. Their major goals include training youths in vocational trades; modernized agriculture such as livestock, poultry and fish farming; create rural employment in the automobile industry amongst others. As part of strategy to achieving these objectives, NAPEP advances micro-credit facilities to her numerous trained clients via community-based financial institutions to effectively empower them in their chosen career.

\subsection{Theoretical Framework}

The connectivity between finance and growth is strikingly undebatable as they are numerous and uncountable positive evidence in that direction. The questionable perspective in this regard is basically the angle of causal relationship. That is to say; is it financial development that triggers or causes growth; agricultural growth in this instance; or vice versa? Extant robust theoretical arguments on the causality direction between finance and growth have spurred three distinguishing theories visa viz; supply-leading theory [49, $42,27]$; demand-leading theory $[43,21,20,26]$; and the bidirectional theory $[11,10]$ respectively.

i. i. Supply-Leading Theory: This theory exists in situations when causal relationship proceeds from financial development to growth. The argument in this sense is that the effective operations of the relevant financial institutions can boost the supply of financial services to the extent that it enhances economic growth. For this study, supply leading theory is corroborated. The situation in developing economies like Nigeria is often that of boosting financial service operations via financial reforms and subsequently directing excess credits from financial sector to agricultural sector through various schemes to boost agricultural development.

ii. ii. Demand-Leading Theory: On the other hand, growth (agricultural growth) within the economy could trigger demand for financial services and subsequently motivates financial development. This is the ideology of the demand-leading theorists. A situation of favorable agricultural productivity in the economy can stimulate economic activities in the rural areas as well as agro allied sector leading to the establishment of more financial institutions.

iii.iii. Bi-directional Theory: The bi-directional theory is upheld in situations where causal link runs in both directions. 


\subsection{Review of Empirical Studies}

Copious empirical positions have so far arisen from the above theoretical arguments over the years in an endeavor to establish the possible connection between financial development and agricultural growth. For instance, research [34] examined Deposit Money Bank`s (DMBs) credit to agricultural sector under the ACGSF in Nigeria. The study evaluated the effect of the explanatory variables of ACGSF, government fund allocation, values of agricultural products, and DMBs' credit to agricultural sector on agricultural productivity. Emanating result showed significant positive effect result for ACGSF and Government fund allocation to agriculture $\mathrm{n}$ agricultural productivity but significant negative effect result for the other variables respectively. Accordingly, the study suggests that farm managers or owners be advised to be sourcing for loanable funds from the participating banks to improve their productivity maximally.

Another study [19] investigated the impact of development banks agricultural financing on economic growth of Nigeria. The primary research objective was to ascertain whether the bank which was purposely set up for the financing of agricultural activities in Nigeria actually fulfilled the object. Utilizing the multiple linear regression technique, the study found that the bank has not lived up to expectation in funding the agricultural activities in Nigeria. The aim of setting up the bank is therefore not attained because of bureaucracy that engulfed the whole procedures and process in its operation. It was recommended that government should intensify effort to ensure there is adequate monitoring of the operation of the said bank so that they actually fund the project that it was set up for.

Another research perspective [35] investigated the impact of commercial bank's credit on agricultural output in Nigeria. The study sought out to establish the relationship between the commercial banks' loan portfolio behavior and the corresponding output of the sector. Apart from the descriptive analytical, approach, an econometric approach was employed in the empirical analysis. The tool of analysis consists of linear regression analysis, indirect least squares, two-staged least squares and co integration analysis. The study found among others that the agricultural sector's output has steadily lagged behind the demand for local consumption and raw material requirements by the industrial sector. In effect, the country has become a net importer of some of her traditional export products such as palm oil and raw cotton. A number of factors were identified as responsible for the dismal performance. Of these factors, inadequate capital is considered as the single most important factor. In similar vein, [22] embarked on the analysis of the future trend of DMBs loans to agriculture and the Nigerian economy. Using the time series simple linear forecasting model, the paper examined the trend of commercial banks credits to the agricultural sector, and made a forecast of the amount of commercial banks credits that would be needed to boost the contribution of the agricultural sector to the nation's GDP in the next 10 years (i.e. between 2003 and 2012) if policy measures such as low exchange rate and interest rate regimes are put in place. The projection showed that as the commercial bank credits increase from $\$ 84775.50$ million in the year 2003 to $\mathbb{N} 197,233.20$ million in the year 2012, the contribution of agricultural sector to GDP would also increase from $\mathrm{N} 211,252.92$ million in the year $2003 \mathrm{~N}$ 4991160.85 million in the year 2012. However, to reach this level, certain policy measures must be put in place by the government and the commercial banks.

\section{Methodology}

Empirical Design and Data: The paper adopted the ex-post facto research design. Accordingly, secondary data on Bank loans to Agriculture in Nigeria, Agriculture Credit Guarantee Scheme Fund, Bank Loans to Small and Medium Scale Enterprises, Bank Loans to Manufacturing sector in Nigeria, Contributions of Agriculture to Gross Domestic Product (GDP), and Nigeria Poverty Index were observed over a 15year period 2005-2019. Data were from the Central Bank of Nigeria Statistical Bulletin. Extracted data were subsequently analyzed and tested to capture the impact of development financing on agriculture and poverty in Nigeria.

\subsection{Research Hypotheses}

Two major hypotheses were formulated in the null form as follows:

$H_{01}$ : Agro-development finance does not have significant positive effect on agricultural development in Nigeria.

$H_{02}$ : Industrial-development finance does not have significant positive effect on poverty eradication in Nigeria.

A'priori Expectation: Consistent with McKinnon-Shaw hypothesis [27] on the roles of financial resources to economic growth, it is expected in this study that development finance will improve agriculture and reduce poverty in Nigeria. As a result, a significant positive relationship is expected to exist between development finance and agriculture as well as poverty reduction. Thus, it is expected that $\beta_{1} \& \beta_{2}>0$.

\subsection{Model Specification and Justifications}

The study employed the multiple linear regression models. The rationale is that the parameter estimates obtained by this method have some optimal properties which include: Linearity, unbiasness and minimum variance. Secondly, the computational procedure of the method is fairly simple compared to other econometric techniques and data requirement are not excessive. Moreover, the method has been employed in similar previous studies including $[18,19,34,12]$. Accordingly, the adopted multiple linear regression models for the two stated hypotheses in are specified thus:

Model 1:

$$
\mathrm{CA}-\mathrm{GDP}_{\mathrm{t}}=\alpha_{1}+\beta_{1} \mathrm{BLA}_{\mathrm{t}}+\beta_{2} \mathrm{ACGSF}_{\mathrm{t}}+\mathrm{e}_{\mathrm{t}}
$$

Where: 
CA-GDP $=$ Contributions of Agriculture to GDP at time $t$;

$\mathrm{BLA}_{\mathrm{t}}=$ Bank loans to Agriculture in Nigeria at time $t$; proxy 1 for development financing; $\mathrm{ACGSF}_{\mathrm{t}}=$ Agriculture Credit Guarantee Scheme Fund at time $t$, proxy 11 for development financing; $\alpha_{1}=$ Constant of the regression equation; $\beta_{1}, \beta_{2}=$ Coefficients of the explanatory variables at time $t$; $\mathrm{e}_{\mathrm{t}}=$ Error term at time $t$.

Model 11:

$$
\mathrm{PI}_{\mathrm{t}}=\alpha_{1}+\beta_{1} \mathrm{BL}_{-\mathrm{SMEs}}+\beta_{2} \mathrm{BL}_{\mathrm{H}} \mathrm{MAN}_{\mathrm{t}}+\mathrm{e}_{\mathrm{t}}
$$

Where:

$\mathrm{PI}_{\mathrm{t}}=$ Nigeria Poverty Index at time $t$, a measure of poverty level in Nigeria; BL_SMEs $\mathrm{B}_{\mathrm{t}}=$ Bank Loans to SMEs in Nigeria, proxy 1 for development financing; $B L_{-} M_{A N}=$ Bank Loans to the manufacturing sector in Nigeria, proxy 11 for development financing; $\alpha_{1}=$ Constant of the regression equation; $\beta_{1}, \beta_{2}=$ Coefficients of the explanatory variables at time $t$; $\mathrm{e}_{\mathrm{t}}=$ Error term at time $t$.

\section{Results and Discussions}

Model 1: The regression model 1 for hypothesis one is translated thus (see appendix 1): -

$$
\mathrm{CA}-\mathrm{GDP}_{\mathrm{t}}=6338.220+27.266 \mathrm{BLA}+5.187 \mathrm{ACGSF}
$$

The above equation shows a constant value of 6338.220 which is positive and significant at 0.006 . This value being the intercept of the regression line indicates that agriculture contribution to GDP in Nigeria would be approximately N6338.220 million holding other explanatory variables constant. Coefficient of bank loan to agriculture (27.266) is positive and significant $(0.000)$ at $95 \%$ confidence level implying that in every $\mathrm{N} 1$ increase in bank loan to agriculture over the time studied, agriculture contribution to GDP increased by N27.266. Similarly, the coefficient of agriculture guarantee scheme fund is 5.187. Hence, a N1 increase in agro-guarantee scheme fund improved agro-GDP by N5.187 over the time studied. The meaning of the above revelation is that agro-finance improved agro-GDP in Nigeria within the studied period.

The above results were further verified by F-statistic. Gujarati and Porter (2009) state that the F-statistics tests model acceptability from statistical perspective by looking at the goodness of fit. If F-statistic significant value (F$\mathrm{Sig})$ is small $(<0.05)$, then the explanatory variables did a good job in explaining the variation in the dependent variable. Checking from the ANOVA, the F-Sig is $0.000<0.05$, an indication that the model did a good job. Confirming the correlational direction between the criterion and the predator variables, the Pearson correlation coefficient was estimated. The coefficient revealed strong positive correlation $(95.5 \%)$ between BLA and CA_GDP; and semi-strong positive relationship (61.3\%) between ACGSF and CA_GDP. The relationship between the predicted and the observed values of the dependent variable is defined by the multiple correlation coefficient $(\mathrm{R})$ whose values range from 0 to 1 . Greater value of $R$ is an indication of strong relationship. $R$ value from the model summary in appendix 1 is 0.956 an indication of strong positive relationship between the predicted and the observed values of the dependent variable. $\mathrm{R}^{2}$, the coefficient of determination is 0.913 implying that $91.3 \%$ of the variations in the dependent variable is explained by the independent variables in the regression model whereas the remaining $8.7 \%$ is due to other factors not accounted for in the model.

Model 11: Regression model 11 for hypothesis two is translated thus (see appendix 2): -

$$
\mathrm{PI}=59.865+0.000 \mathrm{BL}-\mathrm{SMEs}+0.005 \mathrm{BL}-\mathrm{MAN}
$$

The above equation shows a constant value of 59.865 which is positive and statistically significant at 0.000 . It indicates that holding other explanatory variables constant, poverty index in Nigeria would be approximately $59.87 \%$. Coefficient of bank loan to SMEs is 0.000 which is still positive but not significant $(0.115)$ at $95 \%$ confidence level. It means that in every $\mathrm{N} 1$ rise in bank loan to SMEs within the defined study period, poverty index remained unchanged. But bank loan to manufacture slightly changed poverty index by $0.005 \%$.

Checking for significance value of F-statistic from the ANOVA, the F-sig is $0.003<0.05$, an indication that the model also did a good job. The Pearson coefficient of correlation showed strong negative relationship (-77.7\%) between BL_SMEs and PI; and strong positive relationship (79.8\%) between BL_MAN and PI respectively. The R value manifested strong positive correlation at 0.853 between the predicted and the observed values of the dependent variable. Similarly, $\mathrm{R}^{2}$ statistics is high at 0.728 revealing that $72.8 \%$ of the variations in the dependent variable is explained by the explanatory variables in the regression model whereas $27.2 \%$ is due to other factors not accounted for in the model.

\section{Validation of Hypotheses and Conclusions}

Notably, the primary focus of this research is to evaluate empirically the possible effect of development finance strategies on agricultural development and poverty reduction in Nigeria. Evidence arising from the above discussions clearly points to the accomplishment of the set objective. Accordingly, two major findings were made: First, the Pearson correlation coefficient for hypothesis one showed strong positive relationship $(95.5 \%)$ between BLA and CA_GDP; and semi-strong positive relationship (61.3\%) between ACGSF and CA_GDP respectively. But the p-value for ACGSF was not significant 0.841>0.05 hence the rejection of the alternate hypothesis and acceptance of the null hypothesis that; agro-finance does not have significant positive effect on agricultural development in Nigeria. 
Secondly, the Pearson coefficient of correlation for hypothesis two showed strong negative relationship ($77.7 \%$ ) between BL SMEs and PI; and strong positive relationship $(79.8 \%)$ between $\mathrm{BL}$ MAN and PI respectively. The $\mathrm{p}$-values were not significant $0.115>0.05$ (BL_SMEs) and 0.073 $>0.05$. Accordingly, the null hypothesis that industrial finance does not have significant positive effect on poverty eradication in Nigeria was accepted. The above conclusions disagreed with existing studies $[18,34,13]$ but found support in $[35,19]$ amongst others who argue that development finance from financial institutions has not lived up to expectation in funding agricultural activities and curbing poverty in Nigeria.

\section{Recommendations}

Arising from the above conclusions are the following recommendations to fast track the possible benefits of development financing on agriculture and poverty reduction in Nigeria: - i. First, government should place higher priority on directed credit control scheme such as ACGSF to enable such schemes yield the desired result of improving the agricultural sector and poverty reduction.

ii. Secondly, directed credit programmes to SMEs such as small enterprise equity investment and medium scheme (SMEEIS) should be supervised adequately and made to work effectively.

iii. Lastly, for government and private sector based development finance to play effective growth role in the development of the agricultural sector and reduce poverty in the Nigeria economy as a whole, regulatory authority must effectively ensure thorough routine regulation of the aggregate financial system. To this effect, proactive surveillance checks are very imperative in order to checkmate unhealthy practices that could undermine lending integrity and dampen the trust of investors.

\section{Appendix}

\section{Appendix 1: SPSS Regression Output on Development Financing and Agricultural Development in Nigeria}

Table 1. Descriptive Statistics of Development Finance Variables and Agriculture Contribution to GDP.

\begin{tabular}{llll}
\hline & Mean & Std. Deviation & \\
\hline CA_GDP & 13560.1450 & 4958.28936 & 15 \\
BLA & 248.9583 & 170.77196 & 15 \\
ACGSF & 8362712.8358 & 2485750.02890 & 15 \\
\hline
\end{tabular}

Table 2. Correlations between Development Finance Variables and Agriculture Contribution to GDP.

\begin{tabular}{lllll}
\hline & & CA_GDP & BLA & \\
\hline \multirow{3}{*}{ Pearson Correlation } & CA_GDP & 1.000 & .955 & .613 \\
& BLA & .955 & 1.000 & .625 \\
& ACGSF & .613 & .625 & .000 \\
Sig. (1-tailed) & CA_GDP &. &. & .000 \\
& BLA & .000 & .015 & .015 \\
N & ACGSF & .017 & 15 & 15 \\
& CA_GDP & 15 & 15 & 15 \\
\end{tabular}

Table 3. Model Summary ${ }^{b}$ on the Coefficient of Determination $\left(R^{2}\right)$ between Development Finance and Agriculture Contribution to GDP.

\begin{tabular}{|c|c|c|c|c|c|c|c|c|c|c|}
\hline \multirow{2}{*}{ Model } & \multirow{2}{*}{$\mathbf{R}$} & \multirow{2}{*}{ R Square } & \multirow{2}{*}{$\begin{array}{l}\text { Adjusted R } \\
\text { Square }\end{array}$} & \multirow{2}{*}{$\begin{array}{l}\text { Std. Error of } \\
\text { the Estimate }\end{array}$} & \multicolumn{5}{|l|}{ Change Statistics } & \multirow{2}{*}{ Durbin-Watson } \\
\hline & & & & & R Square Change & F Change & df1 & df2 & Sig. F Change & \\
\hline 1 & $.956^{\mathrm{a}}$ & .913 & .894 & 1615.91645 & .913 & 47.283 & 2 & 9 & .000 & 1.523 \\
\hline \multicolumn{11}{|c|}{ a. Predictors: (Constant), ACGSF, BLA } \\
\hline
\end{tabular}

Table 4. ANOVA $A^{a}$ Statistics for CA_GDP and ACGSF, BLA.

\begin{tabular}{llllll}
\hline Model & & Sum of Squares & Df & Mean Square & F \\
\hline \multicolumn{1}{l}{ Regression } & 246930293.481 & 2 & 123465146.741 & 47.283 \\
& Residual & 23500673.885 & 9 & 2611185.987 & \\
Total & 270430967.366 & 11 & & \\
a. Dependent Variable: CA_GDP & & & & \\
b. Predictors: (Constant), ACGSF, BLA & & & \\
\hline
\end{tabular}


Table 5. Coefficients ${ }^{a}$ on the Degree of Changes in CA_GDP caused by ACGSF, BLA.

\begin{tabular}{|c|c|c|c|c|c|c|c|c|c|c|}
\hline \multirow{2}{*}{ Model } & \multicolumn{2}{|c|}{ Unstandardized Coefficients } & \multirow{2}{*}{\begin{tabular}{|l|} 
Standardized \\
Coefficients \\
Beta \\
\end{tabular}} & \multirow[t]{2}{*}{$\mathbf{T}$} & \multirow{2}{*}{ Sig. } & \multicolumn{2}{|c|}{ 95.0\% Confidence Interval for B } & \multicolumn{3}{|l|}{ Correlations } \\
\hline & B & Std. Error & & & & Lower Bound & Upper Bound & Zero-order & Partial & Part \\
\hline \multirow{4}{*}{$\begin{array}{ll} & \text { (Constant) } \\
1 & \text { BLA } \\
& \text { ACGSF } \\
\text { a. Dependent V }\end{array}$} & 6338.220 & 1751.056 & & 3.620 & .006 & 2377.056 & 10299.385 & & & \\
\hline & 27.266 & 3.655 & .939 & 7.461 & .000 & 18.999 & 35.534 & .955 & .928 & .733 \\
\hline & $5.187 \mathrm{E}-005$ & .000 & .026 & .207 & .841 & -.001 & .001 & .613 & .069 & .020 \\
\hline & \multicolumn{10}{|c|}{ a. Dependent Variable: CA_GDP } \\
\hline
\end{tabular}

\section{Appendix 2: SPSS Regression Output on Development Financing and Poverty Level in Nigeria}

Table 6. Descriptive Statistics of Development Finance Variables and Poverty Level.

\begin{tabular}{llll}
\hline & Mean & Std. Deviation & N \\
\hline PI & 61.3942 & 5.21821 & 15 \\
BL_SMEs & 20375.8833 & 12638.49749 & 15 \\
BL_MAN & 1091.6583 & 553.70263 & 15 \\
\hline
\end{tabular}

Table 7. Correlations between Development Finance proxies and Poverty Level.

\begin{tabular}{lllll}
\hline & & PI & BL_SMEs & BL_MAN \\
\hline \multirow{3}{*}{ Pearson Correlation } & PI & 1.000 & -.777 & .798 \\
& BL_SMEs & -.777 & 1.000 & -.704 \\
& BL_MAN & .798 & -.704 & 1.000 \\
Sig. (1-tailed) & PI_ &. & .001 & .001 \\
& BL_SMEs & .001 &. & .005 \\
N & BL_MAN & .001 & .005 &. \\
& PI & 15 & 15 & 15 \\
& BL_SMEs & 15 & 15 & 15 \\
\hline
\end{tabular}

Table 8. Model Summary ${ }^{b}$ on the Coefficient of Determination $\left(R^{2}\right)$ between Development Finance and Poverty Level.

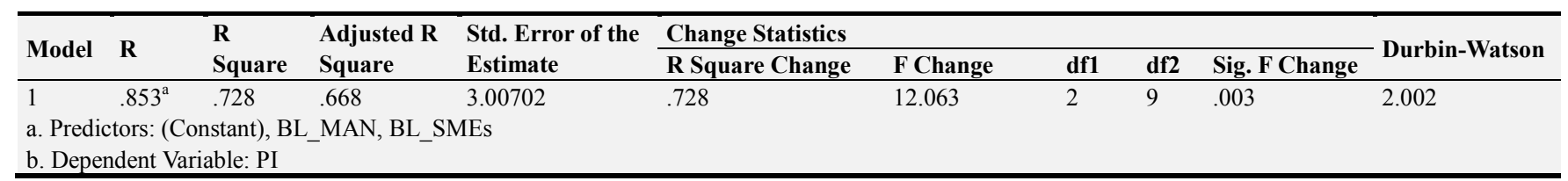

Table 9. ANOVA ${ }^{a}$ Statistics for Development Finance proxies and Poverty Level.

\begin{tabular}{lllllll}
\hline Model & & Sum of Squares & Df & Mean Square & F & Sig. \\
\hline & Regression & 218.147 & 2 & 109.073 & 12.063 & $.003^{\text {b }}$ \\
1 & Residual & 81.379 & 9 & 9.042 & & \\
\multicolumn{1}{l}{ Total } & 299.526 & 11 & & & \\
a. Dependent Variable: PI & & & & & \\
b. Predictors: (Constant), BL_MAN, BL_SMEs & & & & \\
\hline
\end{tabular}

Table 10. Coefficients ${ }^{a}$ on the Degree of Changes in PI caused by BL_SMEs and BL_MAN.

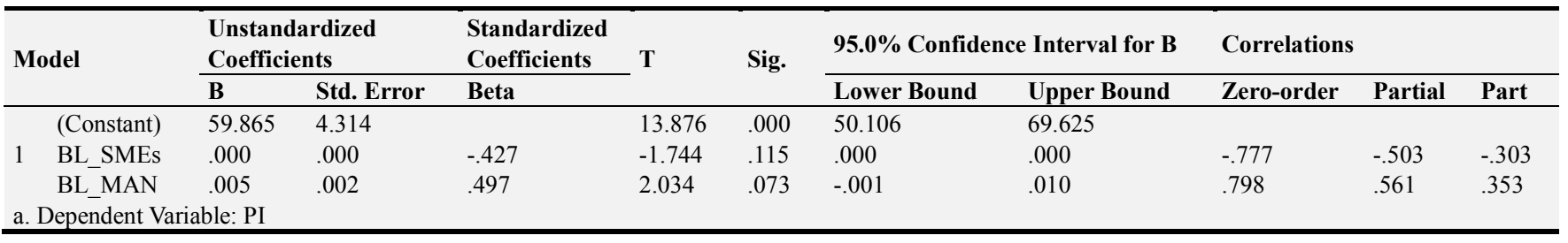

\section{References}

[1] Abu, N. (2009), "Does Stock Market Development Raise Economic Growth? Evidence from Nigeria," Journal of Banking and Finance. 1 (1), 15-26.

[2] Adamu, J. A. and Sanni, I. (2005), "Stock Market
Development and Nigerian Economic Growth" Journal of Economic and Allied Fields, 2 (2), 116-132.

[3] Akinboyo, O. L. (2007), "Micro Finance Bank: Unlocking the Potentials of Micro-Business Activities of the Nigerian Rural Economy" Central Bank of Nigeria Bullion, Vol; 31, No. 1.

[4] Arestis, P. and P. Demetriades (1997), "Financial Development and Economic Growth: Assessing the Evidence", Economic Journal, 107: 783-799. 
[5] Arestis, P., Demetriades, P. O. and Luintel, K. B. (2001), "Financial Development and Economic Growth: The Role of Stock Markets", Journal of Money, Credit, and Banking, 33: $16-41$.

[6] CBN, (2010), Central Bank of Nigeria Annual Report and Statement of Account, Government.

[7] Cem, Disbudak (2010), "Analyzing the Bank Credit-Economic Growth Nexus in Turkey" European Journal of Economics, Finance and Administrative Sciences, ISSN 1450-2275 Issue 23.

[8] Christopoulos, D. K. and E. G. Tsionas (2003), "Financial Development and Economic Growth: Evidence from Panel Unit Root and Cointegration Tests", Journal of Development Economics.

[9] David, M. (2011), "Agricultural Finance and Development", USDA Global Agricultural Information Network, Gain Report No. 10/17/2011.

[10] Demetriades, P. and Andrianova, S. (2004) "Finance and Growth: What We Know and What We Need to Know" University of Leicester Publication.

[11] Demetriades, P. and Hussein, K. (1996), "Does Financial Development Cause Economic Growth? Time Series Evidence from 16 Countries", Journal of Development Economics, 51: $387-411$.

[12] Eleje, E. O. \& Adebayo, G. A. (2016), "Development Financing and Economic Performance in Developing Countries: Empirical Evidence from Nigeria" Salem Journal of Management Sciences, Vol. 2 No. 2, Pg. 1-16.

[13] Eleje, E. O. (2013), "Growth Determinant of Primary Commodity Export Market in Nigeria" Defended Ph.D Thesis, Banking and Finance Department, University of Nigeria Nsukka (UNN).

[14] Eleje, E. O., Nduka, J. A. and Eze, M. C. (2007), "Problems and Prospects of Small and Medium Scale Enterprises in Nigeria", M.Sc. group Seminar Paper, Presented to the Department of Banking and Finance, University of Nigeria, Enugu Campus, October.

[15] Eleje, E. O. and Ani, W. (2012), "Banks' Credit and Economic Performance in Developing Nations: Empirical Evidence from the Production Sector of the Nigerian Economy", India Journal of Finance, Vol. 10 Pp 6-18.

[16] Essien, E. N. And Akpan, N. I. (2007), "Credit Policies and Private Sector Investment in Nigeria" Central Bank of Nigeria Bullion, Vol. 31, No. 1.

[17] Ewah, S. O. E., Essang, A. E. and Bassey J. U. (2009), "Appraisal of Capital Market Efficiency on Economic Growth in Nigeria" International Journal of Business and Management, 4 (12), 219-225.

[18] Ezeoha, A., Ebele, O. and Ndidi, O. O. (2009), "Stock Market Development and Private Investment Growth in Nigeria" Journal of Sustainable Development in Africa, 11 (2), 20-35.

[19] Garber, J. (2010), "Impact of Development Banks Agricultural Financing on Economic Growth of Nigeria" Unpublished M.Sc Dissertation Submitted to the Postgraduate School, Ahmadu Bello University, Zaria.

[20] Goldsmith, R. W. (1969), "Financial Structure and Development" New Haven, Yale University.
[21] Gurley, J. and Shaw, E. (1967), "Financial Structure and Economic Development" Economic Development and Cultural Change, 15 (3) 257-268.

[22] Ijaiya, M. A. (2003), "Commercial Bank Credits to the Agricultural Sector and the Nigerian Economy: An Analysis of the Future Trend" A Journal of Department of Business Administration, Vol. 3 No. 1.

[23] Jung, W. S. (1986), "Financial Development and Economic Growth: International Evidence", Economic Development and Cultural Change, 34: 333-346.

[24] Kolapo, F. T. and Adaramola, A. O. (2012), "The Impact of the Nigerian Capital Market on Economic Growth (1990-2010)" International Journal of Developing Societies 1 (1) 11-19.

[25] Levine, Rose (2003), "Finance and Growth: Theory, Evidence, and Mechanisms" University of Minnesota and NBER Paper.

[26] Lucas, R. E. (1988), "On the Mechanics of Economic Development", Journal of Monetary Economics, 22: 3-42.

[27] McKinnon, R. I. (1973), "Money and Capital in Economic Development”, Washington, DC: Brooking.

[28] Mishkin, F. S. (2007), "The Economics of Money and Financial Markets" Wesley, Pearson/Addison.

[29] NAPEP (2013), "International Day for the Eradication of Poverty” Retrieved Online 14/01/14 via http://www.napep.gov.ng.

[30] Neusser, K. and Kugler, M. (1998), "Manufacturing Growth and Financial Development: Evidence from OECD Countries", Review of Economics and Statistics, 80: 636-646.

[31] Nyong, M. O. (1997). Capital market development and longrun economic growth: Theory, Evidence and Analysis"First Bank Review, 13-38.

[32] Nzotta, S. M. (1999), Money, Banking and Finance: Theory and Practice, Lagos, Intercontinental Publishing.

[33] Obamiro, J. K. (2005), "Nigerian Economy: Growth and the Role of Stock Market" Journal of Economic and Financial Studies, 2 (2).

[34] Obilor, S. I. (2013), "The Impact of Commercial Banks' Credit to Agriculture on Agricultural Development in Nigeria: An Econometric Analysis" International Journal of Business, Humanities and Technology Vol. 3 No. 1.

[35] Ochejele, J. J. (2000) Impact of Commercial Bank's Credit on Agricultural Output in Nigeria, University of Jos Institutional Repository Retrieved 28/06/13 via http://dspace.unijos.edu.ng/handle/10485/1536.

[36] Okafor, F. O. (2011), "50 Years of Banking Sector Reforms in Nigeria (1960-2010) Past Lessons: Future Imperatives" New Haven Enugu, Ezu Books.

[37] Olaitan, M. A. (2006), "Finance for Small and Medium Enterprises: Nigeria's Agricultural Credit Guarantee Scheme Fund”. Journal of International Farm Management 3 (2).

[38] Oluitan (Undated), "Bank Credit And Economic Growth: The Nigerian Experience" Unpublished.

[39] Onayemi S. O and Akintoye, I. R. (2009), "Diversifying the Productive Base of Nigeria, an Economtric Approach to the Assessment of Non-Oil Export Promotion Strategies", International Research Journal of Finance and Economics ISSN 1450-2887 Issue 24. 
[40] Onwumere, J. U. J (2005), “Business and Economic Research Methods" Lagos, Don-Vinton.

[41] Osinubi, T. S. and Amaghionyeodiwe, L. A. (2003), "Stock Market Development and Long-Run Growth in Nigeria, Journal of African Business, 4 (3), 103-129.

[42] Patrick, H. T. (1966), "Financial Development and Economic Growth in Underdeveloped Countries", Journal of Economic Development and Cultural Change 14 (1) 174-189.

[43] Robinson, J. (1952), "The Generalization of the General Theory", In: the Rate of Interest and Other Essays, London: MacMillan Publisher.

[44] Rousseau, P. L. (1998), "The Permanent Effects of Innovation on Financial Depth: Theory and US Historical Evidence from Unobservable Components Models", Journal of Monetary Economics, 42: 387-425.

[45] Rousseau, P. L. (1999), "Finance, Investment, and Growth in Meiji-Era Japan", Japan and the World Economy, 11: 185-198.

[46] Rousseau, P. L. and R. Sylla (2001), "Financial System, Economic Growth, and Globalization", National Bureau of Economic Research Working Paper No. 8323.
[47] Rousseau, P. L. and Sylla, R. (1999), "Emerging Financial Markets and Early U.S. Growth", National Bureau of Economic Research Working Paper No. 7448.

[48] Rousseau, P. L. and Wachtel, P. (1998), "Financial Intermediation and Economic Performance: Historical Evidence from Five Industrial Countries", Journal of Money, Credit and Banking, 30: 657-678.

[49] Schumpeter, J. A. (1912), "Theorie Der Wirtschaftlichen Entwicklung. Leipzig: Dunker and Humblot", The Theory of Economic Development, Translated by Opie, R. Cambridge, MA: Harvard.

[50] Simon, M. K. \& Goes, J. (2013), Dissertation and Scholarly Research: Recipes for Success. Seattle, WA: Dissertation Success LLC.

[51] Thisday, (2013), "Banks and Agriculture Funding in Nigeria", ThisdayLive Saturday 29 June, Retrieved 28/06/13 via $\mathrm{http} / / \mathrm{www}$.thisdaylive.com.

[52] Xu, Z. (2000), "Financial Development, Investment, and Growth", Economic Inquiry, 38: 331-344. 